\title{
First report on the molecular detection, phylogeny, virological and pathological investigations of Avibacterium paragallinarum in chickens in Turkey")
}

\author{
SAJID UMAR ${ }^{*, * * * * * *}$, HASAN ONGOR ${ }^{* *}$, ERHAN BAYRAKTAR ${ }^{* * *}$, \\ HAZAL OZTURK GURGEN****, BELGI DIREN SIGIRCI ${ }^{* * * *}$, ESRA SATIR ${ }^{* * * * * *}$, \\ KAYHAN OZKAN***, NURI TURAN*, AYSUN YILMAZ*, AYDIN GUREL****, \\ SEYYAL AK ${ }^{* * * *}$, BURHAN CETINKAYA**, HUSEYIN YILMAZ* \\ *Department of Virology, Veterinary Faculty, Istanbul University-Cerrahpasa, Avcilar, 34320, Istanbul, Turkey \\ **Department of Microbiology, Veterinary Faculty, Firat University, Elazig, Turkey \\ ${ }^{* * *}$ CEVA Animal Health, Poultry Division, Maslak, Turkey \\ ****Department of Pathology, Veterinary Faculty, Istanbul University-Cerrahpasa, Avcilar, 34320, Istanbul, Turkey

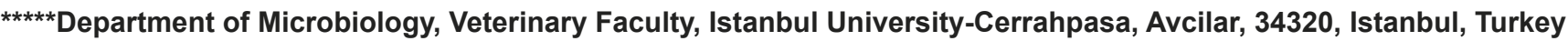

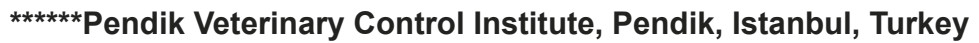 \\ ******Department of Veterinary Pathology, PMAS Arid Agriculture University, Rawalpindi Pakistan
}

Umar S., Ongor H., Bayraktar E., Ozturk Gurgen H., Sigirci B. D., Satir E., Ozkan K., Turan N., Yilmaz A., Gurel A., Ak S., Cetinkaya B., Yilmaz H.

First report on the molecular detection, phylogeny, virological and pathological investigations of Avibacterium paragallinarum in chickens in Turkey

\section{Summary}

Avibacterium paragallinarum is an important pathogen affecting the respiratory tract of chickens. There is a paucity of information on the molecular characteristics and pathology of $A$. paragallinarum in Turkish poultry flocks. In the present study, broiler and layer flocks $(n=2)$ suspected of viral infections with serious respiratory signs and significant mortality were visited. Chickens showed various disease signs and necropsy lesions, including purulent nasal discharge, respiratory distress, facial edema, sticky eyes, mucoid tracheitis, hemorrhagic inflammation of the infraorbital sinuses along with fibrinous mass and conjunctivitis. Histopathological lesions included loss of cilia along with necrosis and exfoliation of the superficial mucosal epithelium of the trachea, facial cellulitis, dermatitis, fibrinous plasmatic edema and infiltration of inflammatory cells, especially heterophils. A. paragallinarum was detected in tissue samples by species-specific polymerase chain reaction (PCR). The sequencing and phylogenetic analysis of the core region of the hemagglutinin (HA) gene revealed that Turkish strains detected here belonged to serotype A (serovar A1). They were related to strains reported from India (VRDC), the United States (0083), and Japan (0221), which are representatives of serovar A1. A homology of 88-90\% was found between Indian strains and the Turkish strains detected in this study. Surprisingly, only vaccine strains of infectious bronchitis virus (IBV) were detected as a co-infecting agent in all samples positive for $A$. paragallinarum. Our findings suggest that $A$. paragallinarum may be an emerging pathogen in Turkish poultry flocks, and direct PCR may facilitate rapid diagnosis of infectious coryza. These results will also help to develop control strategies for $A$. paragallinarum.

Keywords: Avibacterium paragallinarum, chicken, PCR, histopathology, phylogenetic analysis, Turkey

Respiratory pathogens of chickens continue to cause heavy economic losses to the poultry industry worldwide. Respiratory infections are multifactorial, involving environmental factors and various viral and bacterial agents, either alone or in combination,

This research was funded by the University of Istanbul-Cerrahpasa (BAP-27243), Istanbul, Turkey. leading to "respiratory disease complex" $(5,8,9,15$, $20,22,25)$. Rapid and accurate detection of respiratory pathogens has become a challenge because of the involvement of more than one agent with similar clinical signs and lesions, which complicates diagnostic decisions, as well as treatment and control strategies (13). Respiratory disease complexes affect the health 
of birds and increase the overall cost of production in terms veterinary services and treatment. It is therefore important to counter respiratory pathogens in chickens to achieve efficient and profitable production.

Avibacterium paragallinarum, a Gram-negative bacterium from the family Pasteurellaceae, is the causative agent of infectious coryza, an upper respiratory disease of chickens. A. paragallinarum strains are classified into three serogroups (A, B, and $\mathrm{C}$ ) having nine hemagglutinin (HA) serovars (A-1 to A-4, B-1, and C-1 to C-4) (6). The serogroups A, B, and $\mathrm{C}$ represent three distinct immunovars. Most of the commercial vaccines include $A$. paragallinarum in combination with serovars A-1, B-1, C-1, or C-2 (16). The HA protein plays a key role in the virulence and pathogenicity of $A$. paragallinarum and is considered as a potential vaccine candidate.

A. paragallinarum infection causes various signs, including poor growth performance in growing birds and a marked reduction (10-40\%) in egg production of layers (6). The most prominent clinical signs of infectious coryza include acute inflammation of the upper respiratory tract, facial edema, nasal discharge, and conjunctivitis. Likewise, major histopathological lesions include inflammation of the respiratory mucosa with severe damage to the epithelium and infiltration of heterophils (10). Furthermore, severe hemorrhages in tissues of the nasal cavity as well as in sinus infraorbitalis have been reported (21). A. paragallinarum is of paramount importance in the poultry industry because of its worldwide distribution and may contribute to the formation of "respiratory disease complex" under field conditions, thus leading to more severe clinical signs. It has been reported that $A$. paragallinarum provokes acute inflammation of the upper respiratory tract and facilitates the growth of other bacterial and viral pathogens $(16,17)$.

Respiratory diseases are a grave concern for poultry farmers in Turkey as well. The incidence and severity of respiratory diseases in commercial broiler flocks have recently increased in Turkey because of the intensification of the broiler industry. At present, no data are available regarding the molecular characteristics of A. paragallinarum in commercial poultry in Turkey. The aim of this study was to contribute to the knowledge on molecular characteristics of $A$. paragallinarum, which is crucial for implementation of effective control measures.

\section{Material and methods}

Samples, necropsy, and histopathology. Commercial broiler and layer chicken flocks $(\mathrm{n}=2)$ suspected of viral infections with serious respiratory signs and significant mortality were visited in Marmara and Inner Anatolia regions of Turkey in the autumn of 2018 for the diagnosis of the possible causative agents. The chickens were vaccinated against major viral diseases. Sick chickens were evaluated for clinical signs and then euthanized by veterinarians in the farms. Following necropsy and macroscopic evaluation of the chickens, samples of the trachea as well as facial and head tissue were promptly transferred to laboratories for histopathological, virological and bacteriological analyses. For histopathological analysis, samples were fixed in $10 \%$ neutral buffered formalin immediately after necropsy. Tissues were embedded in paraffin, sectioned into 3-5 $\mu \mathrm{m}$ slices, and stained with hematoxylin and eosin (HE). Histopathological analyses were carried out by two certified veterinary pathologists.

Nucleic acid extraction and reverse transcription. Tissue samples were ground, homogenized, and mixed with phosphate-buffered saline (PBS; 0.1 M, pH 7.2) by means of a homogenizer (Ribolyser, Hybaid). The samples were vortexed and centrifuged at $12,000 \times \mathrm{g}$ for $15 \mathrm{~min}$ at $4^{\circ} \mathrm{C}$. Bacterial DNA was extracted from the supernatant of tissue homogenates with a QIAamp ${ }^{\mathrm{R}}$ DNA Mini Kit (Qiagen $\mathrm{GmbH}, \mathrm{D}-40724$, Hilden, Germany) according to the manufacturer's instruction. The DNA was stored at $-20^{\circ} \mathrm{C}$ until use as a template for PCR.

Viral RNA from the samples was extracted using Pure Link $^{\mathrm{TM}}$ RNA mini kits (Invitrogen ${ }^{\mathbb{R}}$ ThermoFisher Scientific, Carlsbad, CA, Cat no 12183018A) according to the manufacturer's instructions. Reverse transcription and generation of complementary DNA (cDNA) for other viruses were performed using a High Capacity cDNA reverse transcription kit (Applied Biosystems, ThermoFisher Scientific, Carlsbad, CA, Cat. no: 00599192) following the manufacturer's protocol. Briefly, a total of $10 \mu \mathrm{L}$ RNA was used in $20 \mu \mathrm{L}$ RT reaction mixture. The RT was performed at $25^{\circ} \mathrm{C}$ for 10 minutes, followed by $37^{\circ} \mathrm{C}$ for 2 hours and finally $85^{\circ} \mathrm{C}$ for 5 minutes. The cDNA was used as the template for PCR amplification.

Detection of $A$. paragallinarum and viral pathogens by PCR. For detection of $A$. paragallinarum, HPG-2 PCR based on a unique randomly cloned fragment of $A$. paragallinarum (7) was used without modification to generate an amplicon of approximately $500 \mathrm{bp}$. HPG-2 PCR was developed by random cloning of the bacterial genome; the role and primer locations in the target gene is still unknown. An optimized PCR reaction, containing $10 \mu \mathrm{L} 2 \mathrm{X}$ AmpMasterTaq master mix (AmpMaster ${ }^{\mathrm{TM}}$ GeneAll Biotechnology, Cambiol, Cambridge, Cat No: 541-010), $2 \mu \mathrm{L}$ of DNA, and $1 \mu \mathrm{L}$ of each specific primer $(10 \mu \mathrm{M})$ in a final volume of $20 \mu \mathrm{L}$, was performed in a thermal cycler (Techne, Staffordshire, UK) to amplify a $500 \mathrm{bp}$ of the genomic DNA of A. paragallinarum. PCR amplicons were analyzed in a $2 \%$ agarose gel (Ultrapure, Invitrogen, Merelbeke, Belgium) containing nucleic acid stain $\left(\mathrm{SYBR}^{\circledR}\right.$ Safe DNA gel stain, ThermoFisher Scientific, Carlsbad, CA) using $1 \times$ TBE as electrophoresis running buffer. Bands were compared with a commercially available 100 bp DNA ladder (ThermoFisher Scientific, Carlsbad, CA) and a positive control.

Samples were also screened to detect the presence of infectious bronchitis virus (IBV) (25), infectious bursal disease virus (IBDV) (24), avian metapneumovirus (aMPV) (5), and infectious laryngotracheitis (ILTV) (26) as part of routine diagnostic work, as described previously. For all PCR reactions to detect either DNA or viral RNA, posi- 
tive and negative controls were used. Positive RNA from vaccine or field samples were the positive control, whereas nuclease-free water was used as the negative control in place of the DNA template.

Amplification of the HA gene of $A$. paragallinarum. The HA gene was amplified for sequencing by means of previously reported primers $(2,14)$. For this purpose, an optimized PCR reaction was performed using $25 \mu$ l of reaction mixture containing $1.25 \mu \mathrm{l}(10 \mu \mathrm{M})$ of each forward and reverse primer, $12.5 \mu \mathrm{l}$ of Maxima Hot Start PCR Master Mix (Thermo Scientific), $6.5 \mu$ l of nuclease-free water, $0.5 \mu \mathrm{L} \mathrm{MgCl}(25 \mathrm{mM})$, and $3 \mu \mathrm{l}$ of DNA.

Sequencing and phylogeny. Amplified PCR products were sent for sequencing to a commercial company (MedSantek, Istanbul, Turkey). Raw nucleotide sequences of the HA gene of $A$. paragallinarum were edited, aligned, and used for phylogeny. The nucleotide sequences of partial segment of the core region of the HA gene were compared with reference sequences of the same genes from the NCBI GenBank. Similarly, any product obtained from the viral RT-PCR was also sequenced, and phylogenetic analyses were performed when applicable.

\section{Results and discussion}

Clinical signs, gross lesions, and histopathology. According to the farmers, routine vaccination programs had been applied against avian viruses (IBV, IBDV, ILT, Newcastle disease and Marek disease), but not against $A$. paragallinarum. Chickens in the farms showed various signs of the disease, including ruffled feathers, respiratory distress, swollen head, submandibular edema, sticky eyes (Fig. 1A), and purulent nasal discharge (Fig. 1B). At necropsy, hemorrhagic inflammation of the infraorbital sinuses was observed along with fibrinous mass (Fig. 1C), conjunctivitis, marked facial tissue edema and hemorrhages as well as gelatinous and cheese-like material (Fig. 1D). There was congestion and marked thickening on the tracheal wall. Mortality rates in clinically affected flocks ranged from $10 \%$ to $16 \%$. Histopathological examination revealed severe facial cellulitis and dermatitis characterized by accumulation of exudate, hyperemia, widespread and diffuse plasmatic edema with fibrin filaments (Fig. 1E) and infiltration of inflammatory cells. Predominant presence of heterophils in comparison to mononuclear cells and macrophages was observed in the dermis and subcutaneous tissue (Fig. 1F). Histopathological findings in the trachea included tracheitis, loss of cilia along with necrosis and exfoliation of the superficial mucosal epithelium. Regenerative epithelial hyperplasia with inflammatory cellular infiltrates in the lamina propria was also noted. Moreover, congested vessels and accumulation of fibrinoleucocytic exudate in the lumen were observed (Fig. $1 \mathrm{G} \& 1 \mathrm{H}$ ).

Detection of $A$. paragallinarum and viral pathogens by PCR. Routine diagnostic screening of viral pathogens revealed the presence of only IBV in all
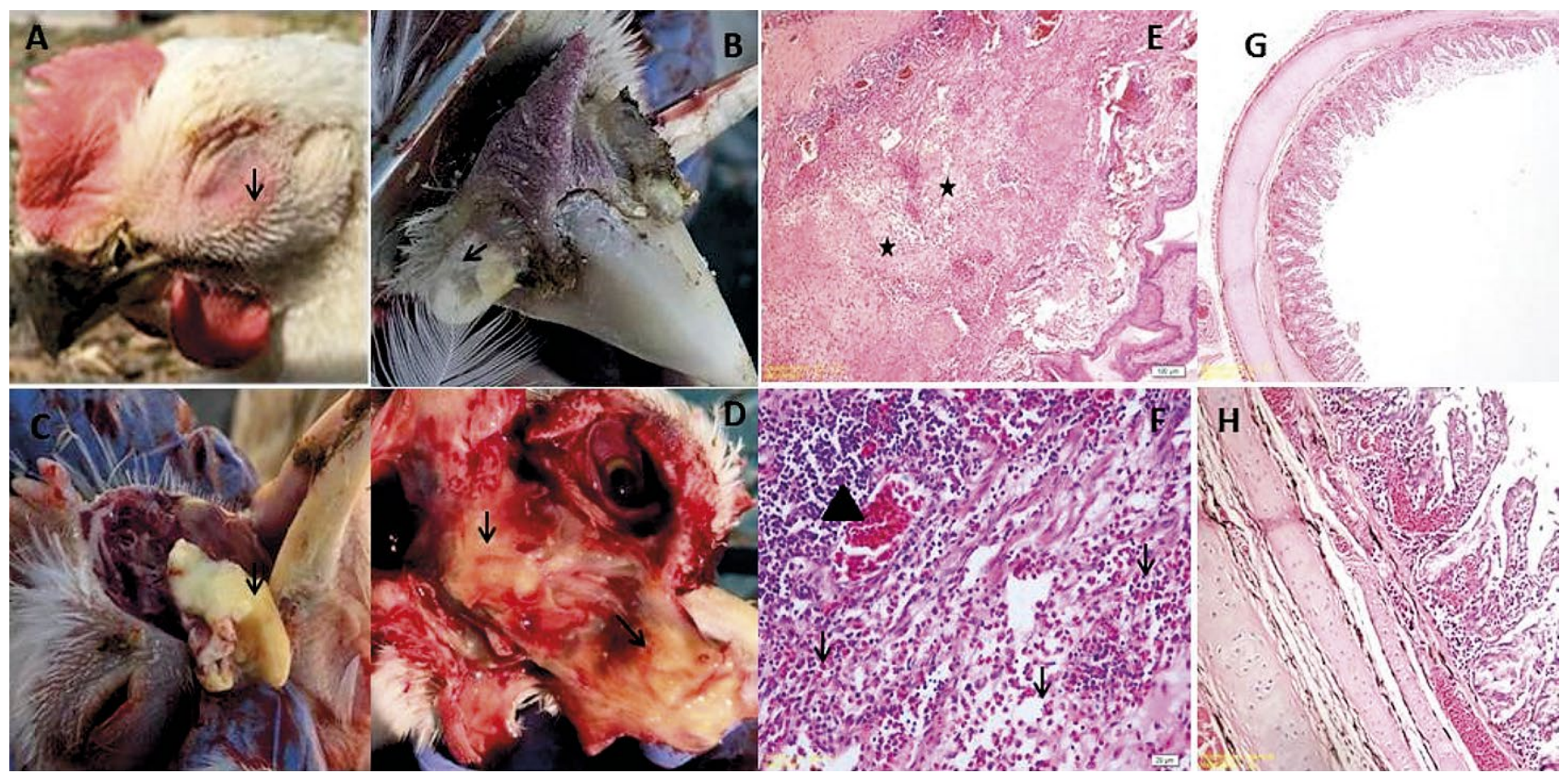

Fig. 1. Macroscopic and microscopic lesions: (A) Swollen head, submandibular edema and sticky eyes; (B) purulent nasal discharge; (C) hemorrhagic inflammation of the sinus infraorbitalis along with fibrinous mass; (D) conjunctivitis, facial tissue edema and hemorrhages along with gelatinous and cheese-like material; (E) hyperemia, widespread and diffuse plasmatic edema with fibrin filaments and infiltration of inflammatory cells (stars). HE. Bar: $100 \mu \mathrm{m}$; (F) Predominant presence of heterophils (arrows) as compared to mononuclear cells (triangle). HE. Bar: $20 \mu \mathrm{m}$; (G) Hyperplastic tracheitis, loss of cilia, papillary proliferation of the epithelium. HE. Bar: $200 \mu \mathrm{m} ;(\mathrm{H})$ Magnified view of the trachea showing hyperplastic tracheitis characterized by papillary proliferation of the epithelium, mononuclear cell infiltration in the lamina propria and congestive vessels. HE. Bar: $50 \mu \mathrm{m}$ 
samples analysed. IBV-positive samples were sequenced and aligned with the other sequences of IBV strains previously published in the NCBI GenBank. The results of phylogenetic analyses showed the presence of IBV vaccine strain. The PCR examination of the DNA samples extracted from tissues of birds with respiratory signs produced amplification products with a molecular size of $500 \mathrm{bp}$, which were indicative of A. paragallinarum (Fig. 2).

Amplification and sequencing of the $\mathrm{HA}$ gene of A. paragallinarum. For sequencing, PCR was conducted to amplify the HA gene of $A$. paragallinarum (900 bp) from DNA samples obtained from birds showing respiratory signs. Then, PCR amplicons were sequenced and aligned with sequences of $A$. paragallinarum previously published in the NCBI GenBank (Fig. 3). Phylogenetic analyses of strains obtained in this study revealed the presence of serotype A (serovar A1) (MK439955, MK439956).

They were related to strains reported from India (KJ621079, KJ621080, KJ621076), USA (KU143735) and Japan (KU143734). Although two A. paragallinarum strains detected in the present study were similar, showing close clustering with each other in phylogenetic analysis, they were partially different from previously reported Indian strains. A homology of $88-90 \%$ was found between the Indian strains and the Turkish strains detected in this study.

Many viral and bacterial diseases are of economic significance in the broiler industry worldwide $(5,6,22,24)$. Although the importance of infectious coryza caused by A. paragallinarum and its economic consequences in broiler flocks have previously been discussed in a number of studies $(10,18)$, the available information on many countries, including Turkey, is limited. The only study carried out in Turkey so far reports the presence of antibodies to serotypes $\mathrm{A}$ and $\mathrm{C}$ in poultry flocks (11). However, there are no published data on the genotyping of $A$. paragallinarum in Turkey. The present study, carried out to investigate for the first time the pathology and molecular characteristics

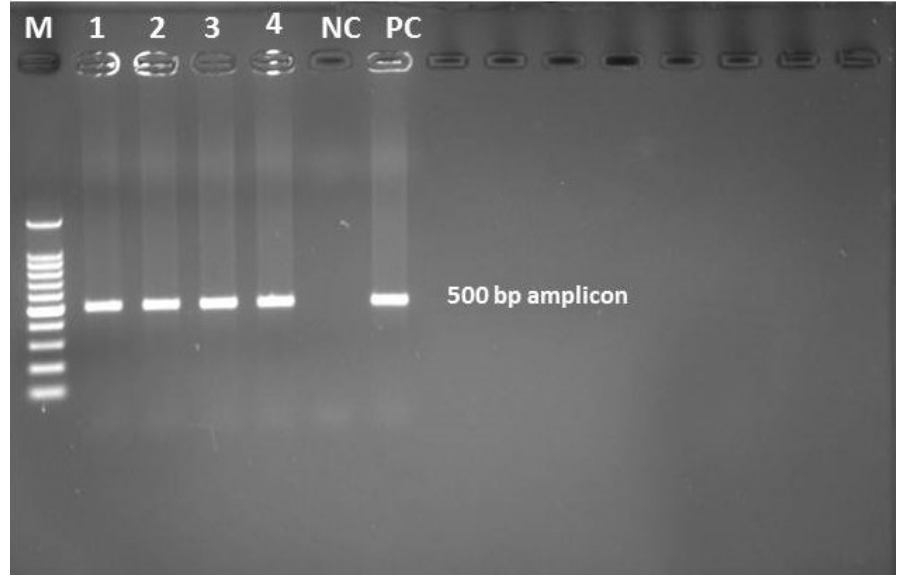

Fig. 2. Molecular identification of $A$. paragallinarum by direct PCR

Explanations: $\mathrm{M}$ - 100 bp marker; 1, 2, 3, 4 - positive samples (1,2 - conjunctiva samples, 3,4 - trachea samples); $\mathrm{NC}$ - negative control; PC - positive control

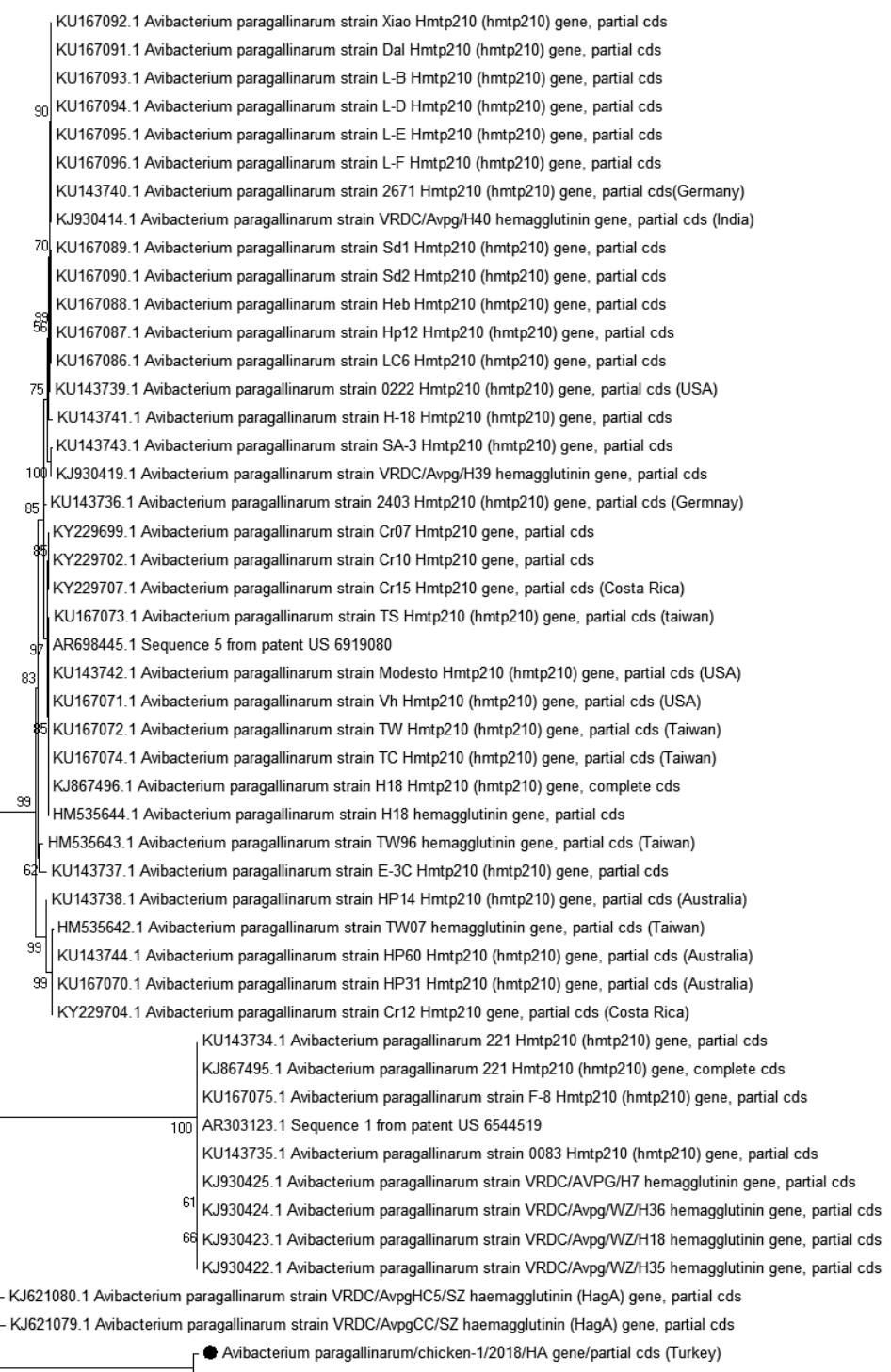

Fig. 3. Phylogenetic tree generated from nucleotide sequences of the HA gene of $A$. paragallinarum field and vaccine strains. The analysis involved 49 nucleotide sequences. The maximum likelihood method based on the Tamura-Nei model with bootstrap analysis of 1,000 repetitions was used. Turkish strains obtained in the present study have been highlighted with black circles 
of $A$. paragallinarum in Turkish poultry flocks, has provided some valuable knowledge about the genetic nature of the pathogen.

The findings of this study suggest that $A$. paragallinarum may be an emerging pathogen in Turkish poultry flocks showing respiratory signs and swollen heads, since mortality reached up to $16 \%$ within two weeks. Outbreaks of infectious coryza produced by A. paragallinarum have been reported to cause higher mortality under field conditions than in experimental trials (15-17). The clinical signs observed in affected chickens, such as ruffled feathers, respiratory distress, a swollen head, submandibular edema, sticky eyes, and purulent nasal discharge, were similar to those reported previously $(10,21)$. In addition, macroscopic findings (fibrinous mass in infraorbital sinuses, facial tissue edema, gelatinous and cheese-like material under the facial skin) and microscopic findings (facial cellulitis and dermatitis with fibrin filaments and infiltration of inflammatory cells) obtained in the current study were similar to those of previous observational and experimental studies $(1,2,10,12,14,17,19,21)$.

Molecular, serological and bacteriological methods have been used for the diagnosis and characterisation of $A$. paragallinarum in chickens $(4,11,17)$. In the present study, molecular methods were employed for the detection and characterisation of $A$. paragallinarum in broiler flocks, and the results indicate that direct PCR from clinical specimens was very successful in rapidly diagnosing infectious coryza, as emphasised by others $(4,7)$, which makes it possible to employ effective antibiotic treatment.

Although serotype A has previously been reported in chickens in Turkey on the basis of serological analyses (11), the phylogeny of $A$. paragallinarum circulating in Turkish chicken flocks is largely unknown. In the present study, the core region of the HA gene was amplified, and the findings were consistent with reports from Hobb et al. (14) and Anjaneya et al. (2). Direct comparison of the results of phylogenetic analysis was not possible, because of the lack of sequence data on $A$. paragallinarum strains from different parts of the world. The sequencing and phylogenetic analysis of the core region of the HA gene confirmed that the strains detected here belonged to serotype A (serovar A1) (MK439955, MK439956). They were related to strains reported from India (KJ621079, KJ621080, KJ621076), USA (KU143735) and Japan (KU143734). Although, two $A$. paragallinarum strains detected in the present study were similar, showing close clustering with each other in phylogenetic analysis, they were partially different from previously reported Indian strains. A homology of $88-90 \%$ was found between the Indian strains and the Turkish strains detected in this study. There might be geographic and temporal relationships between these serotypes. Sequences were not clustered according to Page's serovar scheme of classification.
This result was in agreement with findings reported by other researchers $(2,3,23)$.

In this study, samples were also screened to investigate the potential presence of mixed viral infections as part of routine diagnostic work by PCR. However, none of the samples were found to be positive for the field viruses tested with the exception of the IBV vaccine strain, which was detected in all samples positive for A. paragallinarum. Nevertheless, IBV and $A$. paragallinarum co-infections have previously been reported in many observational and experimental studies (10, 15-17, 21, 22).

This study has provided novel data on the molecular and genetic characteristics of $A$. paragallinarum serotype A in Turkish broiler flocks. A. paragallinarum infections provoke acute inflammations of the upper respiratory tract of broilers, and A. paragallinarum could therefore be considered important for "respiratory disease complex". Bearing in mind that more than one pathogen may be involved in the etiology of respiratory infections, screening for more pathogens can be recommended during routine laboratory diagnosis. The frequency of $A$. paragallinarum infections could be higher in non-vaccinated chickens and in those reared under poor biosecurity conditions. Thus, the application of a suitable vaccine and effective biosecurity measures are essential to prevent a widespread transmission of $A$. paragallinarum and other pathogens. Large-scale molecular studies covering different geographical regions of Turkey will further enhance our knowledge on the distribution pattern and characteristics of $A$. paragallinarum, potentially combined with respiratory co-infections, which is needed to design effective control strategies.

\section{References}

1. Adler H. E., Page L. A.: Haemophilus Infections in Chickens. II. The Pathology of the Respiratory Tract. Avian Dis. 1962, 6, 1-6.

2. Anjaneya, Singh S. D., Dhama K., Wani M. Y., Gowthaman V., Chawak M. M. Molecular Characterization of A. paragallinarum Isolated from Poultry Flocks of India. Asian J. Anim. Vet. Adv. 2014, 9, 440-451.

3. Araya-Hidalgo E., Gutiérrez-Jiménez C., Chaves-Ramírez M., SuárezEsquivel M., Guzmán-Verri C., Barquero-Calvo E.: Sequence analysis of the hypervariable region in hmtp210 of Avibacterium paragallinarum. J. Vet. Med. Sci. 2017, 79, 1210-1214.

4. Askari Badouei M., Sadrzadeh A., Azad N., Blackall P., Madadgar O., Charkhkar S.: Isolation and molecular identification of A. paragallinarum in suspected cases of infectious coryza. Turk. J. Vet. Anim. Sci. 2013, 38, 46-49.

5. Bayraktar E., Umar S., Yilmaz A., Turan N., Franzo G., Tucciarone C. M., Cecchinato M., Cakan B., Iqbal M., Yilmaz H.: First molecular characterisation of avian metapneumovirus (aMPV) in Turkish broiler flocks. Avian Dis. 2018, 62, 425-430

6. Blackall P. J., Soriano-Vargas E.: Infectious coryza and related bacterial infections, [in:] D. E. Swayne, J. R. Glisson, L. R. McDougald, L. K. Nolan, D. L. Suarez, V. L. Nair (eds.): Diseases of poultry, $13^{\text {th }}$ ed. Wiley-Blackwell Publishing, Ames, IA 2013, p. 859-868.

7. Chen X., Miflin J. K., Zhang P., Blackall P. J.: Development and application of DNA probes and PCR tests for Haemophilus paragallinarum Avian Dis. 1996, 40, 398-407.

8. Couto R. M., Braga J. F. V., Gomes S. Y. M., Resende M., Martins N. R. S., Ecco R.: Natural concurrent infections associated with infectious laryngotracheitis in layer chickens. J. Appl. Poult. Res. 2016, 25, 113-128. 
9. Dastmalchi Saei H., Zavarshani M.: Phylogenetic Grouping of Verotoxigenic Escherichia coli (VTEC) Obtained from Sheep and Broiler Chicken in Northwestern Iran. Acta. Vet. Eurasia. 2018, DOI: 10.26650/actavet.2018.010.

10.Droual R., Bickford A. A., Charlton B. R., Cooper G. L., Channing S. E. Infectious coryza in meat chickens in the San Joaquin Valley of California. Avian Dis. 1990, 34, 1009-1016.

11. Findik A., Yardimci H.: The comparison of agglutination, hemagglutination inhibition and indirect hemagglutination tests in the serological diagnosis of infectious coryza in chickens. Ankara Üniv. Vet. Fakalati Dergesi. 2010, 57, 69-72.

12. Fujiwara H., Konno S.: Histopathological studies on infectious coryza of chickens. I. Findings in naturally infected cases. Natl. Inst. Anim. Health Q, Tokyo $1965,5,36-43$.

13. Galal H. M., Tawfek A. M., Abdrabou M. I., Hessain A. M., Alhaaji J. H., Kabli S. A., Elbehiry A., Alwarhi W. K., Moussa I. M.: Recent approaches for control of E. coli and respiratory complex in Middle East. Saudi J. Biol. Sci. 2018, 25, 1302-1307.

14. Hobb R. I., Tseng H. J., Downes J. E., Terry T. D., Blackall P. J., Takagi M. Jennings M. P.: Molecular analysis of a haemagglutinin of Haemophilus paragallinarum. Microbiology (Reading), Engl. 2002, 148, 2171-2179.

15. Kishida N., Sakoda Y., Eto M., Sunaga Y., Kida H.: Co-infection of Staphylococcus aureus or Haemophilus paragallinarum exacerbates H9N2 influenza A virus infection in chickens. Arch. Virol. 2004, 149, 2095-2104.

16. Morales-Erasto V., Falconi-Agapito F., Luna-Galaz G. A., Saravia L. E., Montalvan-Avalos A., Soriano-Vargas E. E., Fernández-Díaz M.: Coinfection of Avibacterium paragallinarum and Ornithobacterium rhinotracheale in Chickens from Peru. Avian Dis. 2016, 60, 75-78.

17. Paudel S., Hess M., Hess C.: Coinfection of Avibacterium paragallinarum and Gallibacterium anatis in Specific-Pathogen-Free Chickens Complicates Clinical Signs of Infectious Coryza, Which Can Be Prevented by Vaccination. Avian Dis. 2017, 61, 55-63.
18. Sandoval V. E., Terzolo H. R., Blackall P. J.: Complicated infectious coryza outbreaks in Argentina. Avian Dis. 1994, 38, 672-678.

19. Sawata A., Nakai T., Kume K., Yoshikawa H., Yoshikawa T.: Lesions induced in the respiratory tract of chickens by encapsulated or nonencapsulated variants of Haemophilus paragallinarum. Am. J. Vet. Res. 1985, 46, 1185-1191.

20. Sid H., Benachour K., Rautenschlein S.: Co-infection with Multiple Respiratory Pathogens Contributes to Increased Mortality Rates in Algerian Poultry Flocks. Avian Dis. 2015, 59, 440-446.

21. Trujillo-Ruiz H. H., Shivaprasad H. L., Morales-Erasto V., Talavera-Rojas M., Salgado-Miranda C., Salazar-García F., Blackall P. J., Soriano-Vargas E. Virulence of Serovar C-1 Strains of Avibacterium paragallinarum. Avian Dis. 2016, 60, 837-840

22. Umar S., Guerin J. L., Ducatez M. F.: Low Pathogenic Avian Influenza and Coinfecting Pathogens: A Review of Experimental Infections in Avian Models. Avian Diseases. 2017, 61, 3-15.

23. Wang H., Sun H., Blackall P. J., Zhang Z., Zhou H., Xu F., Chen X.: Evaluation of a proposed molecular methodology for the serotyping of Avibacterium paragallinarum. J. Vet. Diagn. Invest. 2016, 28, 555-560.

24. Yilmaz A., Turan N., Bayraktar E., Gurel A., Cizmecigil U. Y., Aydin O., Bamac O. E., Cecchinato M., Franzo G., Tali H. E., Cakan B., Savic V., Richt J. A., Yilmaz H.: Phylogeny and evolution of infectious bursal disease virus circulating in Turkish broiler flocks. Poult. Sci. 98, 1976-1984.

25. Yilmaz H., Altan E., Cizmecigil U. Y., Gurel A., Ozturk G. Y., Bamac O. E., Aydin O., Britton P., Monne I., Cetinkaya B., Morgan K. L., Faburay B., Richt $J$. A., Turan N.: Phylogeny and S1 Gene Variation of Infectious Bronchitis Virus Detected in Broilers and Layers in Turkey. Avian Dis. 2016, 60, 596-602.

26. Zhao Y., Kong C., Cui X., Cui H., Shi X., Zhang X., Hu S., Hao L., Wang Y. Detection of infectious laryngotracheitis virus by real-time PCR in naturally and experimentally infected chickens. PLoS ONE, 2013, 8, e67598.

Corresponding author: Prof. Huseyin Yilmaz, Department of Virology, Veterinary Faculty, Istanbul University-Cerrahpasa, Avcilar, 34320, Istanbul, Turkey; e-mail: hyilmaz@istanbul.edu.tr 